\section{Henry Wellcome: the man who made medicine}

\author{
John Launer
}

Between the middle of the nineteenth century and the second world war, the nature of medical practice changed beyond recognition. Much of this happened through advances in the pharmaceutical industry. These included the formulation and mass production of pills and capsules, scientific treatments and vaccines, the standardisation of dosages, the establishment of laboratories for drug research, worldwide systems of manufacture and distribution, direct marketing to doctors, and the dominance of a small number of massively profitable companies to coordinate all this activity. One man was involved in all of these advances and was the prime mover of many of them.

Henry Solomon Wellcome was born in 1853 , the son of a farmer and small town preacher from Minnesota. ${ }^{1}$ As a child he assisted an uncle who ran a surgery and drug store. In his late teens he moved to Chicago and then Philadelphia to train as a pharmacist. After a few years as a highly successful salesman, he took up an invitation to come to London and form a company with an ambitious American colleague, Silas Burroughs. Wellcome turned out to be an entrepreneurial genius, with an perfectionist's eye for design, branding and marketing opportunities, not to mention financial accounts. The business partnership itself went sour with some unpleasant litigation, but after Burroughs's early death in 1895, Wellcome continued to introduce countless new products, and to found factories, laboratories and research institutes around the world, bringing him immense wealth.

The medical innovations attributable to his enterprises included anti-toxins for tetanus, diphtheria and gas gangrene, the isolation of histamine, and the standardisation of insulin. He became a knight of the realm, a Fellow of the Royal Society and a generous philanthropist. At his death in 1936, Wellcome bequeathed all the shares of his company to a trust for medical research. By the 1980s, the company's annual sales were over $£ 500 \mathrm{~m}$, with the

Correspondence to Dr John Launer, Health Education England, Stewart House, 32 Russell Square, London WC1H 5DN, UK; johnlauner@aol.com profits all going to the Trust. In the 1990s, the Trust sold all its shares - including the majority to its one-time rival Glaxo - and replaced them with assets that currently stand at over $£ 21$ billion. Every year, the Wellcome Trust now donates more money to scientists and research centres than the British government gives through its Medical Research Council.

\section{PASSION FOR EXPLORATION}

Wellcome himself seems to have possessed almost supernatural energy and curiosity. He combined his interest in tropical medicine with a passion for exploration and then, later on, with archaeology. On his first expedition in his twenties, he trekked through the jungles of Ecuador to source cinchona bark for the production of quinine as an antimalarial. He ensured that his company dominated the market in portable medicine chests by supplying them to other explorers and travellers including Blériot, Lindbergh, Stanley, Scott and Shackleton. Visiting Sudan at the request of Lord Kitchener in 1910 to assist in a welfare project, he initiated one of the largest archaeological digs of its time at Jebel Moya between the White and Blue Niles, where he incidentally introduced aerial photography for the first time. The excavations proved a relative failure, since the site turned out to be unexceptional in terms of historical significance, but it provided local employment for nearly thirty years, as well as a large number of artefacts for Wellcome's personal collection of historical, scientific and medical objects back in London.

It was as a collector that Wellcome's enthusiasm was most unbounded. He began at quite an early age to keep items like old atlases, tin foil and pencil tins. ${ }^{2}$ As he gained in wealth, his interest gradually extended to medicine chests, old manuscripts and books, decorative vases, pieces of art and sculpture, rugs and naval memorabilia, and other curios to adorn his house in London. From that point, however, his obsession with collecting grew into an enterprise that equalled his pharmaceutical one. He began to amass items of medical, veterinary, scientific, anthropological and archaeological interest on an industrial scale. He hired agents who attended auctions under assumed names, and he bought warehouses to store his purchases. In some years his spending on acquisitions was greater than that of the British Museum, and the total size of his possessions was many times greater than the Louvre.

Wellcome bought whole pharmacies and their contents, but he also collected random objects that had no discernible connection with his known interests, including weapons, armour and a prodigious quantity of worthless junk like old steel safe doors, wood and waste paper. Soon after his death, a rough catalogue of the collection was made for the first time. One part of it listed " 1100 cases of ethnological objects, 100 Graeco-Roman and other classical objects...80 cases of miscellaneous small arms, 150 cases of prehistoric objects, 300 framed pictures...85 cases of surgical instruments...60 cases of pestles and mortars, 170 cases of Peruvian objects...74 cases of weights and measures. ${ }^{2}$ It took forty years to throw away or sell off many of his possessions, distribute others to places like the Science Museum, and retain only the most valuable and important in the Wellcome Collection in London, where they now remain.

\section{SCANDAL OF THE AGE}

If Wellcome's obsession as a collector makes one wonder about his personality, it is not the only cause for doing so. His brief marriage and its aftermath were a scandal of the age. Remaining a bachelor until he was 47 (but lying about his age), he unexpectedly married Syrie Barnardo, some 26 years younger than himself, and the daughter of the famous children's philanthropist. She bore him a son Mounteney, who later turned out to have a mild learning disability and was therefore unable to fulfil Wellcome's hope for a business successor. Syrie did not share her husband's taste for exploration, and actively detested his collection of 'curiosities'. On a joint visit to Ecuador in 1909, Wellcome became convinced that she was having an affair with an American financier, and insisted on separation. Whether or not his accusation was justified, Syrie did indeed have affairs once she returned to London - probably with Gordon Selfridge, the department store owner, and certainly with the writer W. Somerset Maugham, by whom she had a daughter. Wellcome then insisted on a divorce, and Syrie married Maugham, although that marriage too ended disastrously since Maugham was homosexual. Many years later, Maugham brought a court case 
alleging Wellcome had fathered their daughter, but he lost.

Syrie later became an interior designer of great note, but the scandal reverberated for decades, including some venomous memoirs and counter-memoirs from Maugham and his circle that continued after her death in $1955 .^{34}$ In one of these, it was reported that Wellcome had been a sadist who had flogged Syrie with a rhino hide whip, ${ }^{5}$ although since the account was relayed at second or third hand, it has generally been either ignored or discounted by his biographers. An earlier accusation in the newspapers that Wellcome had treated his servants brutally in the Sudan was similarly dismissed by a government inquiry at the time. ${ }^{6}$ Biographers on the whole have been kind to the man, although one sometimes senses a certain reticence in what they write, as well as deference to the Wellcome establishment.

Whatever the truth of such matters, it is clear that Wellcome was not an easy man. Sir Henry Dale, a protégé of Wellcome who won a Nobel Prize for his research on neuro-transmitters, described his former employer as 'curiously lonely."7 Dale went on: "It may be doubted whether anyone knew him with sufficient intimacy to do more than speculate as to his real feelings and motives." An official biography commissioned in 1939 from a man named AWJ Haggis, who also knew Wellcome, was never published, although it has been made available to his biographers and is sometimes quoted by them. Haggis was evidently less circumspect about Wellcome's feelings and motives, and this may have been a reason for the book's suppression. His narrative of Wellcome's marriage and its breakdown includes the following account: "The quarrel with his wife tended to show that an inflexible spirit of intolerance was an underlying feature of his character... In Wellcome, it was apt in extreme cases and on rare occasions to become near to being a self-righteous hypocrisy incapable of distinguishing between the quality of mercy and weakness... He transformed the mental relief and satisfaction he might have gained by a more charitable behaviour into a morbid misery only to be soothed by a vicious preoccupation in his own interests." 5

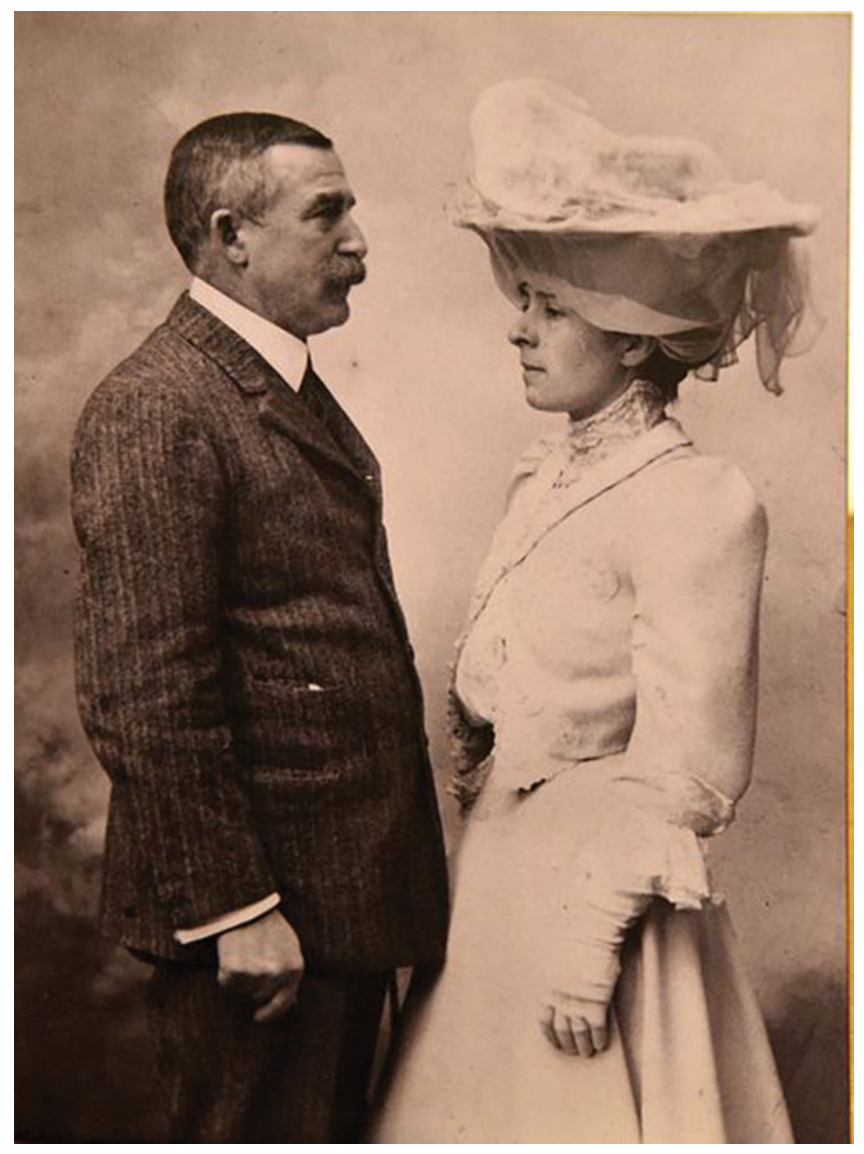

Figure Henry Wellcome and his wife Syrie, c. 1902. Unknown photographer. The Wellcome Collection London. Permission to reproduce this image was granted by Wellcome Library (https:// wellcomelibrary.org/).

This seems a harsh judgement on a man who attained so much. Yet it confirms something we might guess intuitively about Henry Wellcome, even without such an explicit description. His extravagant discoveries, inventions, riches and material objects may have been an attempt to replace externally all the things that he felt he lacked in his own internal world. This does not diminish his achievements, but it may help us to understand them better.

Twitter Follow John Launer @JohnLauner

Competing interests None declared.

Provenance and peer review Commissioned; internally peer reviewed.

(C) Article author(s) (or their employer(s) unless otherwise stated in the text of the article) 2017. All rights reserved. No commercial use is permitted unless otherwise expressly granted.

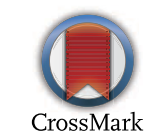

To cite Launer J. Postgrad Med J 2017;93:507-508.

Published Online First 21 June 2017

Postgrad Med J 2017;93:507-508.

doi:10.1136/postgradmedj-2017-135182

\section{REFERENCES}

1 Flannery JA, Smith KM. Sir Henry Wellcome: Backwood to Knighthood. Leeds: Boston Spa Media, 2011.

2 Larson F. An Infinity of Things: How Sir Henry Wellcome Collected the World. Oxford: Oxford University Press, 2009.

3 Maugham WS. Looking Back - Part I. UK: My Maugham Collection Concordance Library. https:// mmccl.blogspot.co.uk/2016/01/looking-back-1.html.

4 Nichols B. A Case of Human Bondage:The Tragic Marriage of Somerset Maugham. London: Martin Secker and Warburg, 1966.

5 McKnight G. Allen WH, The Scandal of Syrie Maugham. London, 1980:38-9.

6 James RR. Henry Wellcome. London: Hodder and Stoughton, 1994:319.

7 Turner H. Henry Wellcome: the Man, his Collection and his Legacy. London: Wellcome Trust and Heinemann, 1980. 